\title{
The governance of inter-organisational relationships during different supply chain maturity phases
}

\section{Evangelia Varoutsa $^{a, *} \quad$ Robert W. Scapens ${ }^{b}$}

\author{
${ }^{a}$ Cardiff University \\ ${ }^{\mathrm{b}}$ Manchester Business School, UK, Birmingham Business School, UK \\ and University of Groningen, the Netherlands
}

*Corresponding author. Tel: +44 (0) 29208 70638; Fax: +44 (0) 2920874419

Cardiff Business School, Cardiff University, Aberconway Building, Colum Drive, Cardiff CF10 3EU United Kingdom

E-mail address: varoutsae@cardiff.ac.uk (E. Varoutsa)

E-mail address: robert.scapens@mbs.ac.uk Tel: +44 (0)161 2754020 (R.W. Scapens) 


\title{
The governance of inter-organisational relationships during different supply chain maturity phases
}

\begin{abstract}
Supply chains and inter-organisational relationships have increased in popularity in recent years and supply chain management has received a vast amount of academic attention. The objective of this paper is to explore the implementation of supply chain management and, in particular, the changing phases of a supply chain as it moves towards maturity. We employ the minimal structure framework of van der Meer-Kooistra and Scapens ["The governance of lateral relations between and within organisations", Management Accounting Research, 2008] to analyse the governance of a supply chain as it moves through the various phases. Drawing on the findings from a case study in an aero-manufacturing company, we explore how the minimal structures emerge and evolve as the supply chain matures.
\end{abstract}

\section{Keywords:}

Supply chain management, supply chain maturity, governance mechanisms, minimal structures

\section{Introduction}

In recent years, the importance and benefits of an effective and efficient supply chain have been widely recognised and supply chain management (SCM) has received increasing attention from many accounting and marketing scholars. Many companies, in some industries more than others, are now working more closely with their suppliers (Christopher, 2000). Scholars have discussed the benefits of developing closer ties with suppliers and the necessary prerequisites, such as rationalising the supply base, achieving a high level of information sharing, establishing cross-organisational teams, and building a trusting and collaborative environment (Ballou, Gilbert, \& Mukherjee, 2000; Johnsen, Johnsen, \& Lamming, 2008). However, implementing these prerequisites is not always straightforward. Furthermore, although the literature points out the key components of 
SCM, it provides little direction on how to implement them. As Lambert et al. (1998) noted more than a decade ago: "the authors appear to assume that everyone knows... what management must do to successfully manage the supply chain" (p. 4).

Some studies report implementation issues and failed attempts, and they state that few companies have actually achieved the claimed benefits of efficient SCM (Akkermans, Bogerd, \& Vos, 1999; Kampstra, Ashayeri, \& Gattorna, 2006; Storey, Emberson, Godsell, \& Harrison, 2006). For instance, Halldórsson et al. (2008, p. 126) pointed out that "there is little empirical research on SCM implementation". Similarly, Chen and Paulraj (2004, p. 151) emphasised that "both academics and practitioners are far from mastering SCM...[as] the complex network of interrelated activities in supply chains makes it challenging for managers to describe and comprehend how those activities are related and how they influence each other", and they called for theoretical models to enhance our understanding of SCM.

In recent years, researchers have started to examine the processes which supply chains go through in an attempt to improve their effectiveness. This process is often labelled supply chain maturity and the supply chain maturity model (SCMM) ${ }^{1}$ has been developed to provide a framework for studying it (such as, Berry, Ahmed, Cullen, Dunlop, \& Seal, 2000; Lamming, 1993; Lockamy \& McCormack, 2004; Mortensen, Freytag, \& Arlbjørn, 2008). Even so, there continue to be calls for further empirical research to provide deeper insights into the supply chain maturity process (McCormack, Ladeira, \& Oliveira, 2008; Mortensen et al., 2008). In particular, more attention needs to be given to the mechanisms of SCM as a supply chain moves through the various phases of the SCMM. In order to address this gap, the current paper explores how a specific company restructured its supply chain. Although the importance of SCM is widely acknowledged, the process of supply restructuring is rarely documented. This paper tackles the important question of what management needs to do to restructure and manage its supply chain.

\footnotetext{
${ }^{1}$ Other authors refer to this process as the "Supply Chain Process Maturity" model (see, for example, Oliveira, McCormack, \& Trkman, 2012). Although the various models differ in the number of phases or the terminology used, they all have the same underlying intention, which is to break down the process of reaching supply chain maturity into distinct phases and to identify the characteristics of each phase.
} 
Our intention is to reveal how organisations can manage the process of restructuring their supply chain. In particular, we study the process that a company operating in the aeromanufacturing industry went through in moving from a very traditional supply chain (with arm's length relationships) to a more mature supply chain (comprising partnerships with its suppliers). We study this company to explore how it restructured its supply chain. We will employ the SCMM to focus on the changing nature of the supply chain as it was restructured through the various phases. We aim to provide a detailed illustration of the development of SCM as the supply chain matures. The intention of the company we studied was to move to the final (maturity) phase quite quickly, but as we will show in our case study, in order to restructure its supply chain it had to go through the various phases of the SCMM.

We focus not only on the control mechanisms which were introduced, but also the way in which the company governed the supply chain relationships that were involved. We will use the notion of governance to capture all the practices used in managing supply chain relationships, including practices that are not actively designed by the parties themselves, but instead emerge through the processes of collaboration. Nooteboom (1999) defined the concept of governance as a much broader notion than control. He argued that "the term 'governance' aims to express that there are multiple interests and that the challenge is to achieve a viable and fruitful balance of interests and power" $(1999$, p. 1). In a later work, Nooteboom (2002) explained that the term 'governance' originated in transaction cost economics, but he extended it to include issues of trust as well as relational risk and transaction costs.

The supply chain we study has a dominant partner which controls all the critical aspects of the supply chain. This partner is a company, operating in the aerospace industry, which has a structured hierarchy of relatively dependent suppliers, who individually present no particular threat to the supply chain, but add value to the dominant partner (Cox, 1999; Shimizu, 1996). Although these suppliers are not easily replaceable (a characteristic of the aerospace industry), and therefore they should have relatively high bargaining power, 
the company studied is dominant, not only because of its market power, but also because of the social responsibility it bears as the supplier of the final product. Nevertheless, it cannot simply control the relationships in a traditional control sense; it needs to govern the relationships.

We believe that the minimal structures framework of van der Meer-Kooistra \& Scapens (2008) offers useful insights into this process as it combines the technical issues involved in control processes with the more social issues, as well as recognising the broader setting, specifically the economic structure and the institutional structure. The framework conceptualises and classifies the elements of a governance package in terms of economic, institutional, social and technical structures. These structures are 'minimal' in the sense that they are not overly constraining; i.e., they provide both firmness and flexibility. As we will explain later, the notion of minimal structures was developed to explore innovation and particularly product development (see Brown \& Eisenhardt, 1997; Kamoche \& Cunha, 2001). Van der Meer-Kooistra \& Scapens (2008) extended the framework to study lateral relationships more generally, and in this paper we draw on their framework to study supply chain restructuring. More specifically, we draw on the minimal structures framework to explore the governance of supply chain relationships. We believe that studying SCM through the lens of the minimal structures framework has the potential to provide useful insights into the governance of a supply chain as it moves through the various phases towards supply chain maturity. In particular, as we will see later, the minimal structures change as the supply chain is restructured through the various phases of the SCMM.

As indicated above, drawing on a case study of a company operating in the aerospace industry, we will illustrate the changes that the company went through in seeking to restructure its supply chain. In so doing, we will contribute, not only to the interorganisational control literature, but also to the supply chain management literature and, in particular, to the literature which discusses supply chain maturity. We will highlight the governance mechanisms and minimal structures needed to move through the various 
phases of the SCMM. Our research question is: how do minimal structures evolve as a company restructures its supply chain?

The remainder of the paper is structured as follows. Section 2 discusses the SCM literature, while Section 3 describes the theoretical framework we use in analysing our case - namely, the SCMM and the minimal structures framework. Next, Section 4 describes our research design and Section 5 presents the empirical findings through the lens of the minimal structure framework. Finally, Section 6 discusses how the minimal structures changed during the supply chain restructuring process and Section 7 adds some concluding remarks, including areas for future research.

\section{Supply Chain Management Literature}

In recent years the SCM has received increasing attention from both academics and practitioners. SCM refers to "the management of multiple relationships across the supply chain... [it] offers the opportunity to capture the synergy of intra- and inter-company integration and management" (Lambert et al., 1998, p. 1). It is "a process for designing, developing, optimizing and managing the internal and external components of the supply system" (Spekman, Kamauff, \& Myhr, 1998, p. 54). Traditionally the marketing literature on supply chains has focused on the characteristics of SCM and the implications for procurement, channels of distribution and demand chain management. It discusses such issues as make-or-buy decisions (see, for example, Alvarado \& Kotzab, 2001; Ballou et al., 2000; Jüttner, Christopher, \& Baker, 2007), the degree of involvement and the number of suppliers (Gadde \& Håkansson, 2001; Gadde \& Snehota, 2000).

Lambert et al. (1998) argued that the implementation of SCM requires the identification of the key members of the supply chain, the business processes which need to be linked together, and the level of integration to be achieved. In a subsequent work Lambert and Cooper (2000) developed a supply chain management framework consisting of three interrelated elements which are necessary for successful management; namely, the supply chain network structure, the supply chain business processes and the supply chain 
management components. ${ }^{2}$ Although Lambert and Cooper (2000) talk about the processes and elements required for successful SCM, they do not discuss in detail how these processes are implemented and evolve as a supply chain matures. Consequently, they called for further research on the processes through which an existing supply chain is modified to increase efficiency and to obtain the desired output (p. 81).

Efficient SCM entails the development of closer, long-term buyer-supplier relationships (Scannell, Vickery, \& Droge, 2000) with "mutual benefits and/or sharing of information, profits and risks" (Kotzab, Grant, \& Friis, 2006, p. 74). Furthermore a strategic purchasing focus requires a reduction in the number of suppliers, as well as a different management style (Spekman, 1988). Spekman and Carraway (2006) argued that collaboration requires an integration of people, processes, structures and information technology. Many studies have highlighted the importance of information sharing within the supply chain (see, for example, Barratt, 2004; Lambert \& Cooper, 2000), and Chen and Paulraj (2004) pointed out that supplier base reduction, improved communication, establishment of long-term relationships, supplier involvement, cross functional teams, and trust and commitment are all critical elements of SCM.

Management accounting researchers have focused primarily on the control of supply chains, and some have discussed cost control through the reduction of shared costs, often referred to as inter-organisational cost management (IOCM) (Agndal \& Nilsson, 2009). A number of research studies have identified the accounting techniques which have been used in inter-organisational settings; such as open-book accounting (Kajüter \& Kulmala, 2005); target costing (e.g., Agndal \& Nilsson, 2009; Mouritsen, Hansen, \& Hansen, 2001) and trade-off techniques (Cooper \& Slagmulder, 1999, 2004). IOCM practices are useful for supplier evaluation and selection in both established and new relationships (Ellram, 2006). The majority of accounting studies focus on a dyadic setting (Håkansson \& Lind, 2007). Nevertheless, a few studies focus on managing the relationships as a whole; i.e., as in networks or supply chains. For example, Dekker (2003) explored the

\footnotetext{
${ }^{2}$ The supply chain management components consist of nine elements that are divided into two groups; namely, the physical and technical management components and the managerial and behavioural management components.
} 
implementation of value chain analysis and, in particular, the use of activity-based costing as part of the SCM practices of a retail firm. He argued that two control issues arise in managing inter-organisational relationships; the need to manage interdependence and the need to manage appropriation concerns. Cooper and Slagmulder (2004) identified four types of suppliers; ranging from family members to general suppliers and argued that each type of suppliers needs its own IOCM techniques.

Nevertheless, for the governance of inter-organisational relationships and the integration of supply chain activities, cost reduction techniques and other control mechanisms are not sufficient; broader forms of governance are likely to be required. As a supply chain moves through the different phases of the SCMM, different forms of governance are likely to be needed in each phase (Caglio \& Ditillo, 2008; Cullen \& Meira, 2010). Thus, as we will illustrate in the next section, our theoretical framework draws on the SCMM and the minimal structures frameworks.

\section{Theoretical Framework}

In our case study we will use the SCMM to map the development of SCM practices and the minimal structures to analyse and theorise those practices. The SCMM is an evolutionary framework which will provide a way of mapping the changes in the supply chain over time. As such, the SCMM gives the analysis a processual dimension, while the

minimal structures framework provides a way of looking at the governance needs and management practices at each stage in the process.

\subsection{Supply Chain Maturity Model - The influence of supply chain maturity on governance needs}

In this section we outline the SCMM, illustrate the characteristics of each phase and discuss the different governance needs as a supply chain moves from a simple buyersupplier relationship to mutual dependency, which Lockamy and McCormack (2004) characterise as a shift from an internally-oriented approach to an externally-oriented approach. Although various models and terminologies are available in the literature (see footnote 1 above), we will adopt the terminology of Berry et al. (2000) who distinguish 
four phases; namely the autonomous firm phase, the serial dependence phase, the reciprocal dependence phase, and the mutual dependence phase.

The first phase, the autonomous firm phase, comprises traditional arm's length marketbased relationships. This phase is characterised by a lack of close interaction and collaboration between suppliers-buyers. Traditional accounting techniques, which focus on the identification of the lowest cost alternative through competitive bidding, can be sufficient for the management and control of these relationships (Cullen \& Meira, 2010; Lamming, 1993). The transaction environment comprises many potential suppliers and the market price will be the main criterion for the choice of supplier. Transactions are characterised by low asset specificity, significant repetition and high output measurability. The control mechanisms implemented by the buyer will focus on the measurement of quantity, quality and timeliness of delivery (van der Meer-Kooistra \& Vosselman, 2000). Such characteristics are specified in the contract and no specific or sophisticated control instruments are needed for the management of this type of relationship. So in this early phase, traditional management accounting techniques are adequate for the governance of the supply chain relationships (Cullen \& Meira, 2010).

The second phase, the serial dependence phase, entails identifying preferred/dominant suppliers who are encouraged to invest in the relationship and to commit themselves to the supply chain (Berry et al., 2000). This phase can be considered as the 'breakthrough' phase (Lockamy \& McCormack, 2004) as it is the beginning of a more collaborative relationship. Consequently, SCM has a more strategic intention. The focus of this phase is to reduce the supplier base by identifying preferred suppliers with whom closer and more collaborative relationships can be developed. Spekman (1988) argued that "cooperation, whereby firms exchange bits of essential information and engage some suppliers/customers in longer contracts... [is a] starting point for SCM and has become a necessary but not sufficient condition" (p. 55). Lambert and Cooper (2000) distinguish between primary and supporting members of the supply chain, where the former add value to the output of the supply chain, whereas the latter do not. Initial steps towards information sharing with primary suppliers can be observed during this phase, through 
techniques such as open book accounting, ${ }^{3}$ which Mouritsen et al. describe as "a strategy that leads towards co-operation between firms situated in a supply chain, and this information is used to influence the flow of products and services between the firms in question" (Mouritsen et al., 2001, p. 225). Cullen and Meira (2010) pointed out that the majority of studies focus on the serial dependence phase, where one partner aims to control the other(s).

In the third phase, the reciprocal dependence phase, there is an increasing realisation of the importance of the relationships (Lamming, 1993). This leads to greater collaboration with preferred suppliers and the establishment of long-term strategic relationships (Lambert \& Cooper, 2000). As the parties work more closely together there is a need for more information sharing (Caglio \& Ditillo, 2012). Christopher (2000) suggested that information sharing can be leveraged through process integration; i.e., "collaborative working between buyers and suppliers, joint product development, common systems and shared information" (p. 39). Typically, the suppliers become involved in the early stages of the design and manufacturing process. Involving suppliers in product design increases flexibility, especially in modular products (Stevenson \& Spring, 2009), and there is a focus on improving costs and creating value (Coad \& Cullen, 2006) further upstream in the supply chain (Agndal \& Nilsson, 2009).

Finally, in the fourth phase, the mutual dependence phase, where collaboration with suppliers has been firmly established, the focus is on the development of a partnership arising from mutual interests and mutual respect (Berry et al., 2000; Lamming, 1993). Behavioural considerations, such as commitment, trust and mutuality, are significant in this phase. The focus is on the relationship with, rather than the performance of, the supplier (Johnsen et al., 2008). Furthermore, in this phase advanced management practices will be in place; for example, the measurement of process performance and the establishment of cross-organisational teams (Lockamy \& McCormack, 2004). The sharing of accounting information is now necessary, not only for the contract

\footnotetext{
${ }^{3}$ Cullen and Meira (2010) categorised the inter-organisational studies according to the maturity of the studied relationship and identified a plethora of studies which provide evidence of open book accounting.
} 
negotiations, but also for the governance of the relationship. In particular, cost data will be shared (Seal, Cullen, Dunlop, Berry, \& Ahmed, 1999) and target costing may be used (Lockamy \& Smith, 2000).

Thus, as we can see, as a supply chain moves through the different phases of the SCMM the governance needs change and consequently the supply chain restructuring is likely to be accompanied by governance changes. Based on the above discussion, we would anticipate that in the early phases, particularly in autonomous firm phase, the governance of the relationships will have a largely economic focus. In contrast, in the later phases where relationships become closer and collaboration more intense, both in terms of the organisations and the individuals involved, economic governance is unlikely to be sufficient. In these later phases the governance of the relationships is likely to need social, as well as technical elements. As we indicated above, we will explore the governance changes in our case study of the supply chain restructuring in an aeromanufacturing company through the lens of the minimal structures framework. It is to this framework we now turn our attention.

\subsection{Minimal Structures Framework}

Van der Meer-Kooistra and Scapens (2008) drew on the organisational theory literature to develop a framework for studying the governance of lateral relationships in two cases; one of relationships between companies and the other of relationships within a company. Both cases were characterised by the following features: the exchange of information and knowledge creation; the combination of co-operation and competition; the need for both flexibility and standardisation; and a changing leadership role. Building on the work of Kamoche and Cunha (2001), who in turn drew on the work of Brown and Eisenhardt (1997), van der Meer-Kooistra and Scapens (2008) developed a minimal structures framework to study the governance mechanisms which, in the context of lateral relationships, can support and promote these features.

Kamoche and Cunha (2001), who developed their concept of minimal structures in the context of product development, argued that a minimal structure is needed as a template 
within which innovation can take place. They identified two types of minimal structures, social and technical structures, which do "not serve to constrain action or limit options" (p. 745), but instead provide an effective way of managing the contradictory demands of control and creativity by balancing the need for both structure and flexibility. They argued that minimal structures facilitate a dialectical approach as they provide clearly defined and "appropriate levels of responsibilities, priorities and procedures...combined with wide zones of manoeuvre" (emphasis in original: p. 750). Building on these arguments, van der Meer-Kooistra and Scapens (2008) went a step further and developed a more general framework that can be used for the governance of lateral relationships. They added two additional types of structure to accommodate the organisational and environmental embeddedness of lateral relationships. Specifically, they added an economic structure, which includes the economic aspects of transactions between the parties, and an institutional structure, which comprises the rules and regulations set by governmental and other external bodies as well as those set within the organisational context.

So, van der Meer-Kooistra and Scapens distinguished four minimal structures for the governance of lateral relationships; economic, institutional, social and technical structures (see Table 1 for examples of elements of the four structures). The economic structure contains the economic aspects of the transactions between the parties. It comprises the economic character of the relationship, the economic context within which the relationship takes place and the economic arrangements agreed by the parties, such as prices and efficiency norms, the length of the relationship, the frequency and volume of transactions, the time schedules and quality requirements. The institutional structure sets the institutional context of the relationship, comprising both the external environment including legal and other regulations - and the broad organisational arrangements which shape the governance mechanisms.

--- Insert Table 1 about here --- 
The social structure consists of the social ties between the parties which determine the character of their relationship. The social structure recognises that trust is an essential element in the governance of lateral relationships. Some degree of trust between the parties is essential because of the co-operative nature of lateral relationships between autonomous parties. As van der Meer-Kooistra and Scapens explain, "trust can be built where the governance of these relationships provides sufficient structure to mitigate the risks which are involved in co-operation between independent parties who may have different motives and interests, while at the same time allowing individual capabilities and knowledge to be exploited for the mutual benefit of all the parties" (p. 381). Finally, the technical structure comprises the technical context of the relationship and sets the technical requirements of the transactions.

All the elements of the minimal structures illustrated in Table 1 are not expected to be seen in every lateral relationship, since the specific characteristics of each relationship will determine the elements of each structure. However, van der Meer-Kooistra and Scapens argue that, as a whole, the minimal structures provide a "coherent set of structures" (p. 375) for any particular lateral relationship. Here, we need to be clear about the differences between the terms 'elements' and 'mechanisms'. Whereas mechanisms are consciously designed and implemented by the parties, elements as parts of the individual minimal structures are not necessarily consciously designed. Elements are a broader concept than mechanisms; they comprise both mechanisms and the other elements which set the context for the governance of the relationships.

The minimal structures framework includes both internal (e.g. organisational arrangements) and external (e.g. law and governmental regulations) elements, as well as elements that evolve over time, such as trust and integrity between the parties and changes in the environment of the relationship. The minimal structures provide the firmness and flexibility which are needed in the governance of the relationship. The notion of minimal (structures) does not relate to, say, the 'size' or number of elements which make up each structure, but to the way in which they balance firmness and flexibility. As such, minimal structures provide sufficient structure, while at the same 
time providing 'room for manoeuvre' - i.e., flexibility. Firmness is "the degree to which rules, policies and procedures govern the role behavior and activities of organizations" (Van de Ven \& Ferry, 1980, p. 303). Too much firmness can reduce the flexibility needed to execute the necessary actions (Rosenthal, 1992). Therefore, there is a need to balance firmness and flexibility and, according to van der Meer-Kooistra and Scapens, the minimal structures should provide an appropriate level of firmness and flexibility.

Minimal structures provide boundaries which do not seek to overly constrain behaviour, but instead they define a relatively broad area while leaving sufficient room for autonomy to be exercised within those boundaries - i.e. a zone of manoeuvre. The firmness of the structures will depend upon the context of the relationships. As Tatikonda and Rosenthal (2000) explained, minimal structures provide "flexibility within a structure; i.e. firmness in the sense of having a predetermined structure, and flexibility in the nature of work within that structure" (emphasis in original: p. 417). In cases of high levels of uncertainty, instability and changing environments, structures with wide zones of manoeuvre will be needed to provide the flexibility required to adapt quickly to new circumstances without prior planning and authorisation. However, in cases where the environment of the relationship is characterised by stability and low levels of uncertainty, wide zones of manoeuvre are unnecessary and practices can be more or less predefined and standardised; i.e., more structured. The requirement to have both firmness and flexibility in the governance of lateral relationships reinforces the need for trust between the parties (van der Meer-Kooistra and Scapens, 2008).

The minimal structures framework provides a way of studying how the governance package evolves as a supply chain moves through the various phases of the SCMM. The combination of the four minimal structures (economic, institutional, social and technical) is likely to be different in each of the phases. For example, the governance of the autonomous firm phase is likely to be very different to the governance of the mutual dependence phase. In the autonomous firm the governance of the relationships is likely to have a largely economic structure, possibly together with an institutional structure in such a highly regulated context as the aerospace industry. In contrast, in the mutual 
dependence phase, where the parties are working very closely together, the social and technical structures are likely to be more important. However, we do not know how the minimal structures evolve as the supply chain moves from one phase to another. We expect that the combinations of the minimal structures, and their relative importance, will evolve as the supply chain matures. In our case study we will seek to identify the minimal structures in each phase as the company restructures its supply chain.

In contrast to many other accounting studies (see, for example, Agndal \& Nilsson, 2009; Kajüter \& Kulmala, 2005; Mouritsen et al., 2001), we are not primarily concerned about the specific management control techniques which are used; rather we are interested in how the various management controls can combine to form a governance package. Nevertheless, in our case study we will briefly mention some specific accounting techniques which are particularly interesting in this context. The advantage of using the minimal structures framework for our analysis is that it enables us to look at the governance package as a whole (rather than at the specific elements) and to explore how all the elements fit together to form a package. Currently, there is increasing debate in the accounting literature about the differences between a 'system' and a 'package' (see, for example, Giovannoni \& Scapens, 2014; Malmi \& Brown, 2008; Sandelin, 2008). Malmi and Brown (2008) termed the combination of various control systems a management control package. However, Giovannoni and Scapens (2014) conceptualised a package as a broader notion than a system, comprising not only such management controls as accounting and performance measurement systems, but also other formal mechanisms such as training activities, codes of conduct, behavioural constraints as well as more informal mechanisms. However, in this paper we do not need to enter this debate as the minimal structures framework provides us with a way of conceptualising the governance package in terms of the economic, institutional, social and technical structures.

\section{Research Design}

To study the various phases of the SCMM and to explore the evolution of the minimal structures through these phases, we will draw on a case study of a company in the aerospace industry which, in order to maintain confidentiality, we will refer to as AIR. 
The aerospace industry is a very competitive knowledge-based industry with high levels of complexity, high quality and integrity of products, and high rates of outsourcing. In recent years production and delivery delays due to design problems and difficulties with global supply chains, as well as substantial cost overruns, have been common (RoseAnderssen, Allen, Tsinopoulos, \& McCarthy, 2005; Rose-Anderssen et al., 2006). There is now increasing recognition within the industry that traditional supply chains, comprising simple buyer-supplier relationships, may not be effective and can lead to production delays and limit the development of new products. Thus, we believe that the aerospace industry and the particular company (AIR) provide a suitable context in which to study supply chain restructuring and to address our research question.

In 2004 AIR, which procures externally $70 \%$ of the components in its final products, decided to reformulate its global supply chain strategy. As a result, over the past decade it has significantly changed its relationships with its suppliers. Although the company operates in a range of business segments, our field work took place in its primary facility in the aerospace industry. The focus of the study was the supply chain for a specific component used in the manufacturing process. We studied the effect of the company's restructuring strategy on one specific supply chain in order to provide a more complete understanding of how the strategy was implemented. This particular supply chain was selected because it is the most complex and significant, not only because of its size, but also because it represents a major element of one of AIR's primary products.

The main source of data was semi-structured interviews with the employees of AIR who are closely involved in the management of this particular supply chain and, more specifically, in the restructuring of this supply chain. During the interviews we asked the interviewees about the supply chain restructuring and the governance mechanisms they were using. The interviews were conducted during ten site visits between September 2006 and March 2009. Data for periods before September 2006 had to be collected retrospectively (Leonard-Barton, 1990). In total, we conducted 20 semi-structured interviews with 11 senior managers, middle-level managers and accountants, representing various departments - i.e., finance, purchasing and operations (see Appendix A). We 
obtained detailed information about the management of the supply chain which is the focus of our study and also about its context. ${ }^{4}$ The interviews were conducted face-toface, and ranged from one to two hours in length. They were recorded and transcribed verbatim for subsequent analysis. However, two interviewees did not wish to be recorded and so detailed notes were taken during those interviews and consolidated afterwards. Furthermore, additional data was collected from various documentary sources. Access was granted to a significant number of company documents, such as contracts, management reports, scorecards and other formal documents. Data was also collected from publicly available sources; namely, newspaper articles and press releases, presentations to investors, and the company's annual reports.

We followed the company both during and after the process of restructuring the supply chain and we analysed the changes that took place in AIR's relationships with its suppliers and the changes in its management practices. In the early stages of data analysis we used NVivo for the thematic coding of the interview transcripts. The purpose of coding was not to count things, but to "fracture" the data (Strauss, 1987, p. 29) and to rearrange it into categories suitable for addressing our research question. We created seven free nodes and six tree nodes that organised the interview data according to, for example, the different chronological periods, supplier relationships and control mechanisms $^{5}$ (see Appendix B for details of the nodes). The data collected consisted of interview transcripts, field notes and relevant documents. The first steps in the data analysis - i.e., reading the interview transcripts and other documents (Emerson, Fretz, \& Shaw, 1995) - took place simultaneously with the data collection process. Subsequently, we employed a narrative strategy, which involves the "construction of a detailed story from the raw data" (Langley, 1999, p. 695). So after data had been organised by the thematic codes, a case report was written and enriched with detailed descriptions of the practices as well as quotes from the interviewees. During this process, the nature of the changes led us to the SCMM, which we then decided to use to complete the analysis. As the SCMM is an evolutionary model it provided us with a framework for understanding

\footnotetext{
${ }^{4}$ The findings presented here are part from a larger research project - see (Varoutsa, 2011).

${ }^{5}$ These nodes were selected when conducting the analysis for the larger project mentioned in footnote 4.
} 
the changes over time. During the final stages of the analysis we returned to the data, looking at each of the phases separately and trying to identify the minimal structures in each phase. The relationship between the phases of the SCMM and the minimal structures will be discussed in the next section.

Due to the qualitative nature of this study, the traditional criteria of reliability, validity and generalizability, which are commonly used in quantitative research, are not appropriate (Miles \& Huberman, 1994, pp. 278-280; see also, Ryan, Scapens, \& Theobold, 2002), so we needed alternative criteria. Various alternatives are available, many dating back to Lincoln and Guba (1985); for example, Wagner, Lukassen \& Mahlendorf (2010) use the criteria of credibility, transferability, dependability and confirmability. In this study, we have used the criteria of procedural reliability, authenticity and plausibility ${ }^{6}$, and transferability (see Ryan et al., 2002). Like dependability, procedural reliability refers to the appropriateness of the procedures which have been used (Wagner, Lukassen, \& Mahlendorf, 2010). We sought to achieve this by using an appropriate research design and appropriate data collection and analysis techniques. For example, as indicated above, most of the interviews were recorded and transcribed, and detailed notes were kept where this was not possible. Authenticity and plausibility are achieved by collecting sufficient and credible evidence to support the analysis (cf. credibility and confirmability). We employed various data collection techniques and used both internal and public documents to corroborate what we were told by the interviewees. Furthermore, information collected in the early interviews was discussed in subsequent interviews to seek both clarification and confirmation. Probing questions were also asked so as to confirm our understandings and to increase the credibility of the evidence collected (McKinnon, 1988). Finally, as we were not seeking to generalise our findings in AIR to a broader population, the criteria of transferability seemed more appropriate. This means that we want to demonstrate that the framework which we have used for understanding AIR's supply chain restructuring can be useful for studying other organisations and other contexts.

\footnotetext{
${ }^{6}$ Authenticity and plausibility could also be considered a form of contextual validity (Ryan et al., 2002).
} 


\section{The Restructuring Process and Governance of AIR's Supply Chain}

\subsection{Background}

AIR is a leading UK-based manufacturing company which has numerous subsidiaries and employs over 20,000 people globally. ${ }^{7}$ It has a range of business segments, one of which is in the aerospace industry, where it is a system integrator and provides the final product to the customer. In 2004, following the trend in the aerospace industry, AIR decided to restructure its supply chains to improve their efficiency by increasing collaboration with its suppliers. As pointed out earlier, in this paper we will study how AIR's supply chain restructuring was implemented in the supply chain of an intermediate component for its primary product in the aerospace industry. Over the last decade AIR has significantly changed its supply chain strategy towards a much greater focus on supplier relationships, thereby seeking to create competitive advantage through efficient SCM. Initially, it initiated a supply chain simplification programme across all its business segments and activities. Because of the size of the company we decided to explore the implementation of this programme in one specific supply chain. We chose this particular supply chain because of its size, significance for the final product, and the extent of the changes which occurred during the restructuring. Before the restructuring process, the supply chain we studied comprised approximately five hundred arm's length relationships, as well as three joint ventures (JVs). The result of the restructuring process was to significantly reduce the number of these arm's length relationships (to about forty) and to achieve much closer collaboration with those remaining in the supply chain. During the restructuring process the JVs continued to act as suppliers, but they also underwent major changes. We should mention that in AIR there is no obligation to buy internally (e.g., from the JVs) if the terms are unfavourable.

We also need to clarify the meaning of the terms 'transactions' and 'projects' in this supply chain, as we will use both terms in our analysis. In the case of AIR, a transaction with a supplier is not for the supply of a particular material or service at a specific point in time, but an agreement to provide a continuing supply, involving a large number of deliveries, over a period of time. Our interviewees generally referred to transactions with

\footnotetext{
${ }^{7}$ The exact figure is withheld to preserve the anonymity of the company.
} 
suppliers as 'projects', and in the early phases of the SCMM a project was for the supply, over a period of usually three to five years, of a specific component, material or service. However, as the supply chain matured, and suppliers became more closely involved in the design and manufacturing processes, the definition of a project became rather unclear.

In the following sections we will describe the changes in the governance mechanisms as the supply chain was restructured. We will illustrate how AIR implemented its global supply chain simplification strategy in the studied supply chain. As indicated above, we will organise this description in four chronological periods and map them according to the phases of the SCMM. AIR's practices before 2004, which primarily comprised oneoff transactions and arm's length relationships, fit the autonomous firm phase. In 2004, AIR took the decision to restructure the supply chain and to radically reduce its supplier base. We map this 'breakthrough' (Lockamy \& McCormack, 2004) as the serial dependence phase. Subsequently, we map to the reciprocal dependence phase the changes that occurred during 2004-2006 as AIR increased collaboration with its key suppliers and entered into long-term agreements with them. Finally, the practices implemented after 2006 suggest that AIR had achieved the mutual dependence phase. In this case AIR wanted to develop partnerships with its suppliers (i.e., to move to the mutual dependence phase) but, as we will see, it nevertheless had to move through the various phases of the SCMM, although it did this relatively quickly. We will now look at each of these phases in turn and we will identify and analyse the minimal structures in each of the phases.

\subsection{The Autonomous firm phase}

Prior to 2004, AIR's attitude towards its suppliers corresponded to the first phase of the SCMM - the autonomous firm phase (Berry et al., 2000). At that time, before the restructuring, AIR was following the traditional style of purchasing and allocated clearly defined activities to numerous suppliers with which it had arm's length relationships. There was low asset specificity and thus it was relatively easy to change suppliers. AIR allocated projects to the suppliers with the lowest quotes. Most contracts were for three years, and this discouraged suppliers from investing in machines and new technology. Furthermore, suppliers had no impact on the product design stages, and this often led to a 
mismatch between the manufacturing capabilities of suppliers and AIR's design expectations. As a consequence, AIR had to face not only delays down the supply chain, but also increased costs of the final product.

In this early phase of the SCMM, the institutional structure was quite important for the governance of the relationships. The aerospace industry is closely regulated by national and international public bodies due to the high social and environmental impact of the industry's products. The purpose of these regulatory bodies is to ensure the highest safety standards, which presume very high product quality and result in stringent quality control requirements. To do this, they form expectations and enforce standards regarding the quality procedures of manufacturing companies and the practices and requirements related to outsourcing. As a JV Relationship Manager ${ }^{[8] 8}$ commented:

Within this industry, everything is measured at the quality level and everything is recorded and controlled much more than in other industries. That's an interesting aspect of the industry, which maybe differs from other industries. The quality sequence has to be mapped out from the very beginning to the very end. The extent of such a procedure differs from other industries.

Due to the regulated nature of the aerospace industry, the institutional structure existed prior to the allocation any specific project. In the aerospace industry, the industry's regulators - both national and international - set quality standards for aerospace products. Consequently, a project will only be allocated to suppliers who can meet these quality standards. As such, the institutional structure influences the criteria that have to be met by potential suppliers.

In addition, the economic structure also had an important role in this early phase. The economic structure emerged with the allocation of a project. The only mechanism in place for the governance of these traditional relationships was the contract review process which comprised the activities needed for the specification of the quality, delivery and cost requirements of a project. There was no requirement for any further information and

\footnotetext{
${ }^{8}$ The number in square brackets refers to the interview number in the Appendix A.
} 
the project would be allocated to the supplier that met the quality and delivery requirements and offered the lowest quote. As a purchasing manager ${ }^{[3]}$ explained:

The purchasing department would do a commodity strategy on its own, just as though purchasing was the end of the road. And whenever there is a part needed to be sourced, purchasing people would go out, they would receive the quotations, and develop the metrics. So it's like, what's the cost developed by the supplier, what's the quality, delivery, lead time? And then we called on the CRB [Contract Review Board], where stakeholders from all disciplines, such as logistics, quality, and project, were presented with the outcomes of the purchasing activity...However, it was decided that this was a very bureaucratic process as there was a CRB called on for every source and decision.

AIR focused almost exclusively on these (quality, delivery and cost) characteristics of the projects, as set out in the contract review process. As these characteristics were included in the operational contracts, along with other important information, such as the price of the allocated project, the length of the relationship and the manufacturing and technical requirements, these contracts set the broad economic structure for the governance of the relationships. Furthermore, as there was a contract there was an expectation, stemming from contract law (part of the institutional structure), that the supplier would honour the contract terms.

At that time (i.e., prior to 2004) AIR had clearly-defined, contractually-based transactions. The relatively short timeframe of these contracts and the lack of the suppliers' involvement in the design process did not encourage the building of relationships of trust and collaboration between AIR and its suppliers. Consequently, a social structure was not present in this early phase. Furthermore, the contribution of the technical structure, which comprises the technical context of the relationship, was limited. A technical structure was not very important at that time in the sense that it was not needed to govern the relationship. Once the contract was signed, the technical requirements were defined and the suppliers had to follow the contract's technical requirements. Table 2, which summarises the minimal structures during the autonomous 
firm phase, illustrates that in this early phase of the SCMM, which comprises traditional supplier-buyer arrangements, it was largely the economic structure, together with the institutional structure that governed AIR's supply chain relationships. Both structures were quite 'firm' and left relatively little room for manoeuvre. So the balance between firmness and flexibility was very much in favour of firmness.

\section{---Insert Table 2 around here ---}

\subsection{The Serial dependence phase}

As indicated above, in 2004 AIR initiated various changes to improve the efficiency of its global supply chain in an attempt to improve its overall performance. As already mentioned, the aerospace industry is high regulated, and furthermore it is subject to significant competitive pressures for continuous improvement. In recent years aerospace supply chains have come to be regarded as very problematic and there has been a trend within the industry to streamline supply chains and to increase collaboration with suppliers (Deloitte, 2009). Around this time AIR was part of a network of aerospace manufacturers which was promoting supply chain restructuring. ${ }^{9}$ Furthermore, AIR was receiving quite negative feedback from some of its suppliers. As the senior operations purchasing manager ${ }^{[5]}$ explained:

The working relationships team received some feedback from traditional suppliers and they said, you are too complex, you are too arrogant, and you don't value us. We don't trust you, we only have deals for a small period of time and we cannot invest. You are too cold in your transactions, so if you don't do something right, we will move somewhere else.

Given these circumstances, AIR decided to appoint consultants to evaluate the performance of its supply chain and to measure the satisfaction of its suppliers and customers; and the results were very worrying. Having analysed the consultants'

\footnotetext{
${ }^{9}$ For example, AIR was a one of the founding members of the Society of British Aerospace Companies (SBAC). In 2006 SBAC launched its $21^{\text {st }}$ Century Supply Chains (SC21) Action Plan which aimed at improving the (British) aerospace industry's competitiveness by increasing supply chain performance, and it published an updated version of the SCRIA (Supply Chain Relationships in Aerospace) Code of Practice which was aimed at promoting improvements in supply chain relationships (www.adsgroup.org.uk).
} 
feedback and the expectations of the industry's regulators, AIR decided to restructure its supply chains at a company level, focusing on reducing the number of suppliers and developing close relationships with the remaining key suppliers. AIR's actions correspond to the second phase of the SCMM - the serial dependence phase (Berry et al., 2000) - during which companies identify their preferred suppliers and encourage them to invest in the relationship in order to reduce the costs of the supply chain (Lamming, 1993).

In this phase of the SCMM we see the institutional structure beginning to shape the changing relationships. The institutional structure exists prior to any specific project/relationship, but as the supply chain matures the institutional structure becomes more important. Pressures from both the external and internal environment of AIR shaped its decision to restructure its supply chains and to develop collaborative relationships with its suppliers. The consultants' report indicated that both AIR's customers and its suppliers were unhappy with AIR's attitude and performance, and some even questioned whether they would work with AIR on future projects. They also pointed out that AIR had very complicated supply chains, with numerous points of contact, which often led to confusion and delays. As the senior operations purchasing manager ${ }^{[5]}$ also pointed out:

We had strong feedback from the supply chain saying that AIR is crazy and compared [unfavourably] to XYZ (AIR's competitors). So that's where we said okay, yes, we have a problem...we need to come and look at different techniques and tools to manage supply chains or else we are going to end up in a very difficult situation.

As a result AIR developed a new global supply chain strategy which was intended to rationalise its supply base (by reducing the number of suppliers and no longer working with poorly performing suppliers) and to develop closer relationships with its major suppliers which would eventually lead to partnerships between AIR and these major suppliers. For AIR, a 'major supplier' is one that is important for the continuity of the manufacturing process. In this phase, AIR realised the importance of supply chain 
performance, identified its major suppliers and sought to collaborate quite closely with them. It should be noted that because of the regulated nature of the industry, the highly technical nature of its products and the high entrance barriers in the aerospace industry, close relationships can only be developed with suppliers already operating within the industry. The economic structure remained important in this phase as it helped to facilitate the process of identifying the preferred suppliers. Furthermore, a social structure started to emerge as the preferred suppliers were identified, and as AIR encouraged them to invest their capacity and technology in the relationship. In the studied supply chain, AIR wanted to reduce the number of suppliers from approximately 500 to about 40 , with whom the intention was to work much more closely and to delegate to them some of the supply chain responsibilities (i.e., as Tier 1 suppliers). As a purchasing manager ${ }^{[4]}$ pointed out, "we wanted to give more capabilities to the supply chain". In this context the preferred suppliers had to be suppliers whom AIR trusted to collaborate effectively with them.

So in this serial dependence phase, the economic and institutional structures continued to govern relationships with the suppliers (as indicated in Table 3 which summarises the minimal structures during the 'serial dependence' phase). One might argue that the influence of the external environment on AIR's supply chain practices was due largely to the regulated nature of the industry. Nevertheless, even in industries which are not as highly regulated there may still be institutional norms which establish and secure 'acceptable standards' of performance in order to protect customers and consumers. Also in this serial dependence phase, AIR's intention to develop collaborative relationships with its (smaller group of) suppliers led to the emergence of a social structure; a structure which will evolve more specifically in the next phase - the reciprocal dependence phase. So, although the economic and social structures remained relatively firm, there was an increasing need for some 'room for manoeuvre' and the emerging social structure provided the basis for governing this flexibility. As such, the balance between firmness and flexibility was beginning to shift in the direction of more flexibility. Although this serial dependence phase was very short (taking place largely in 2004), it represented the first step in restructuring the supply chain away from the autonomous firm phase and it 
quickly led on to the reciprocal dependence phase. As such, it provided the necessary 'breakthrough' (Lockamy \& McCormack, 2004) needed to move into the third phase during which the social structure could evolve.

\section{---Insert Table 3 around here---}

\subsection{The Reciprocal dependence phase}

AIR's next actions in restructuring the supply chain we studied can be mapped in terms of the third phase of the SCMM - the reciprocal dependence phase (Berry et al., 2000). This phase is characterised by increased collaboration between the buyers and suppliers (Lamming, 1993). In AIR the result of this collaboration was longer contracts and the suppliers' early involvement in the design and manufacturing processes. As the dominant partner AIR has considerable power over the supplier, but as it moved into the reciprocal dependence phase it started to give up some of this power by entering into long-term agreements with its suppliers. Typically, these agreements were for five to ten years during which time the suppliers were expected to share knowledge and technology and to procure raw materials for the manufacturing process. These longer contracts were put in place to address the suppliers' concerns that the traditional three year contracts were not sufficient for them to recover their investments in new technology. Furthermore, the potential suppliers ${ }^{10}$ were involved in the early design stages so as to take advantage the suppliers' expertise and to increase the flexibility of product designs. As the purchasing manager ${ }^{[4]}$ noted:

We now have a two-way design and engineering interaction. What we try to do is ask 'what is the best way to make it?'... We try to get them involved earlier, more like a design to target cost, and that way we are moving away from the traditional 'give me a quote'. You now have transparent costing by working together... [Also] involving the suppliers as early as possible in new programmes reduces project risk and enhances the probability of success.

\footnotetext{
${ }^{10}$ The suppliers were asked to contribute the design stages even before they were allocated the project.
} 
During this phase the social structure became much more important in the governance of the relationships. There was a need for relationships of trust between AIR and its suppliers in order to facilitate the exchange of sometimes commercially sensitive information, even before signing long-term agreements. For example, before such agreements were signed suppliers were expected to disclose financial information and AIR often discussed with suppliers such sensitive issues as their managers' attitude towards confidentiality. From the suppliers' perspective, in order to invest in such a relationship and to participate in one-sided open book accounting, goodwill trust was needed - i.e., trust that the other party has a moral commitment to the relationship and will not act opportunistically (Sako, 1992). The longer term contracts which AIR was signing with its suppliers, demonstrated AIR's willingness to improve its relationships with its suppliers and to invest in the supply chain. Furthermore, trust was needed for the implementation of new governance mechanisms. Initially, AIR developed a series of key performance indicators (KPIs) to measure the performance of its JVs, with the intention of subsequently extending them to the other suppliers (as we will see in the next phase). As a finance manager ${ }^{[7]}$ explained: "the idea originally was to pilot it with the JVs and then any mistakes and any learning points..., we could then take them and work with the other suppliers".

Through the supply chain restructuring, AIR was not only seeking to improve the financial situation of the JVs, but also to change their manufacturing decisions and strategic goals, as well as implement a strategic orientation. Therefore, it attempted to increase control over the JVs through the implementation of such operational and financial KPIs as cost, quality, delivery and inventory indicators. The development of these new mechanisms provided the groundwork for the evolution of the technical structure for the governance of the supply chain relationships. Furthermore, the early involvement of suppliers in the design process meant that the technical structure was becoming increasingly important in shaping the supply chain relationships. As the suppliers worked together with AIR in designing the technical requirements of the products, the technical structure defined in technical terms what was expected from them. 
It was during this phase that we saw for the first time the use of accounting information in the governance of the supply chain relationships. In the case of the JVs, financial information was (and still is) reported on a monthly basis through the financial KPIs. In contrast, for the long-term agreements, financial information was disclosed only during the negotiations which took place at the beginning of the relationship. Nevertheless, there was an increasing awareness that this practice was not sufficient; as the financial director ${ }^{[2]}$ pointed out:

We should do a financial assessment every two years. But in reality, you tend to stick with the same suppliers, so when another project comes up a year later, you will do it again for that project. You would run a new assessment, not because you sourced the work but because you want to source new work. So you get the information, but not in the right way of doing it.

During this phase of the SCMM, the contribution of the economic structure was limited to the choice of the appropriate mode of collaboration. ${ }^{11}$ Once long-term agreements are set up, the economic structure contributes little to the governance of the relationships. The restructuring of the supply chain and the long-term agreements with suppliers resulted in a need for additional information beyond the economic aspects of the relationship. In addition, the institutional structure was no longer as important in the governance of the relationships (as in the previous phases). Although the elements of the institutional structure arising from the regulated nature of the industry continued to be important, they were largely in the background as they were taken for granted by everyone involved.

As AIR moved through the phases of the SCMM, trust became increasingly important. In the case of the JVs, AIR attempted to establish a relationship of trust through greater transparency and two-way communication. For example, AIR provided support and assistance to the JVs when needed. As a financial controller ${ }^{[6]}$ explained: "they [the JVs] now take a lot of our best people, business methods engineers; they all go out to those

\footnotetext{
${ }^{11}$ As Table 4 shows, the elements of economic structure are the same as those which had emerged in the previous phase. As the economic structure moved into the background during this phase no new elements emerged.
} 
places [the JV sites] to help them". Furthermore, in the case of the other suppliers, the long-term agreements and the more frequent interactions between AIR and its major suppliers increased familiarity across the supply chain and this helped to build trust. As a result, in this phase we see the social structure becoming more important in the governance of the supply chain. This social structure facilitated information sharing and the initial development of governance mechanisms, such as the KPIs. Subsequently, the information generated from these governance mechanisms contributed to the evolution of the technical structure.

The long-term agreements and the suppliers' involvement in the design stages made the technical structure increasingly important in enabling AIR and its suppliers to work together. So, as we move into these later phases of the SCMM, and as collaboration with suppliers increases, there is a shift in the relative importance of the minimal structures which govern the relationships. The economic and the institutional structures become less important, while the evolving social structure becomes more important and a new technical structure emerges. As flexibility is becoming important in the governance of the relationships between AIR and its suppliers, the firmness previously provided by the economic and institutional structures becomes less important (as they would limit flexibility), but the social and technical structures are needed to secure an appropriate balance between firmness and flexibility. The structures and their elements are illustrated in Table 4, which sets out the minimal structures in the 'mutual dependence' phase. As we will see below, in the next and final phase of the SCMM, the social and technical structures continue to gain importance in the governance of the supply chain.

\section{---Insert Table 4 around here---}

\subsection{The Mutual dependence phase}

From 2006 AIR could be said to be in the final phase of the SCMM, the mutual dependence phase, in which there is a partnership arising from the mutual interests and mutual respect of all the parties in the supply chain (Berry et al., 2000). In this phase, AIR completed the restructuring of its supply chain and, together with its suppliers, it 
developed new mechanisms, such as a supplier scorecard and a relationship profile tool, to measure the performance of the supply chain and to govern the relationships with suppliers.

During this phase the technical structure evolved quite significantly, and the technical information that was generated further increased the importance of this structure. More specifically, in 2006, AIR introduced a new supply chain strategy, which was the final step in its supply chain restructuring. This strategy first set out the procedures to be followed in procuring raw and intermediate materials and other commodities (the commodity strategy), and then provided well-defined and documented guidelines for the management of suppliers (the suppliers strategy). The purpose was to align the performance of the supply chain with both AIR's corporate strategy and its customers' requirements. The commodity strategy gathers in one place all the relevant information related to the commodities and projects over a period of ten years, such as the strategic plans, technological requirements, performance indicators and current and potential suppliers. To develop a partnership of mutual interests, in 2006 AIR started to draw up the supplier strategy jointly with its suppliers, with the aim of identifying, developing and delivering the long-term business objectives of both AIR and its suppliers. As a purchasing manager ${ }^{[20]}$ commented: "we are not signing a ten year contract, we are doing a ten year strategy". The supplier strategy specifies the preferred type of relationship, the adequacy of the supplier's current performance, the need for technology-sharing, and the development of capabilities and plans for improvement if needed. ${ }^{12}$

The technical structure evolved further with the development of cost management techniques and, in particular, the technical information generated through target costing. In the previous (mutual dependence) phase, we saw that AIR began involving suppliers in the early stages of the design and manufacturing of processes. This enabled target costing to be introduced. AIR identified target costing as a mechanism which would improve information flow and communication at both cross-functional and cross-organisational

\footnotetext{
${ }^{12}$ The supplier strategy includes the following stages: supplier early engagement, establishment of AIR's vision for the supplier, establishment of the supplier's vision for AIR, agreement of common strategic objectives, common development and approval of the supplier strategy, and the deployment of the strategy.
} 
levels. Representatives from the design and manufacturing departments, as well as the purchasing and marketing departments, were all involved and interacted with the supplier's representatives in order to set target costs. However, target costing was imposed on suppliers in a quite aggressive way. As a financial controller ${ }^{[15]}$ commented:

We are going to design the target cost...we tend to be inquisitive...we tend to use a very assertive way of understanding whether we are getting fair and reasonable costs.

In addition, AIR further strengthened the technical structure during this phase through the implementation of new performance measures. In particular, it developed a Supplier Advanced Business Relationship (SABRe) tool. This is a web-based system which is updated on a six-monthly basis in order to capture best practices. It is designed to support and improve suppliers' existing quality control systems and to align them with AIR's quality policy. It sets out AIR's requirements regarding the performance of its suppliers and the improvement plans which they need to implement in order to match the performance of AIR's internal operations. These requirements are discussed with suppliers and displayed on their individual supplier's scorecards which record their performance in terms of quality, cost and delivery using ten key performance indicators (KPIs). The purpose of applying a unified set of KPIs for all the suppliers (which are similar to those used for the JVs and by AIR internally) was to achieve integration and communication. As the senior operations purchasing manager ${ }^{[12]}$ explained:

The scorecard compares all aspects and allows the purchasing department, when they start to do work, to understand whether they should be exiting the supplier. It doesn't matter if it's a partnership or not, are they a good supplier to get new work when you get a new load coming in? The lower ranking suppliers, who already supply to us, are put on an improvement process and monitored by the higher managers throughout AIR. So we rely on that scorecard approach to assess the performance of the supplier and it works very well.

During this phase, the social structure also became more important in the governance of the relationships with suppliers. The social structure was reinforced through the 
establishment of cross-organisational teams with members from both AIR and its suppliers. These cross-organisational teams facilitated the team-working and information sharing which were necessary to develop the supplier strategies and to implement the governance mechanisms described above. As an operations manager ${ }^{[17]}$ commented: "I think that it is vital... at least we can communicate and tell each other what's really happening in a relationship". For example, the supply chain strategy is driven by an integrated product team which has members drawn from the purchasing, finance, engineering and logistics departments of both AIR and its suppliers. By creating both cross-organisational and cross-functional teams, AIR was seeking to overcome communication problems and to achieve consistency across the supply chain, through greater transparency and effective information sharing within the teams.

Despite the increasing importance of the social structure in this phase, we observed some attempts by AIR to reduce personal social ties. In inter-organisational relationships there is a need for flexibility in social relationships in order to be able to react to unexpected situations. However, AIR seemed to want to reduce this flexibility through the introduction of specific governance mechanisms which set out its expectations about the norms and values of appropriate behaviour in supply chain relationships. Up to this point, AIR had attempted to improve supply chain performance by building strong personal relationships between the people involved. However, building strong personal relationships may not be enough on its own, especially in the aerospace industry which is characterised by high staff turnover. As there is a risk that the benefits of good interpersonal relationships can be lost during the handover procedure when someone leaves, AIR attempted to develop a mechanism to promote the openness, trust and honesty that good personal relationships require.

Thus, AIR, with the assistance of consultants, developed a relationship profile tool which attempts to provide a structure upon which good relationships can be built independently of the specific individuals involved. The relationship profile is jointly completed by AIR and each supplier, and it provides an opportunity for both parties to identify any problematic issues, to jointly decide on improvement plans and to document their shared 
expectations about the norms and values of appropriate behaviour. It is a complex and sophisticated tool as it addresses many subjective and difficult to quantify issues, such as mutual respect and mutual benefit, transparent processes, collaboration, trustworthiness, relationship management, long-term integrity and two-way communication. As a purchasing manager ${ }^{[20]}$ commented

...to get a better long-term view, the characteristics we need to focus on are not always price, not always quality, not always delivery, but the relationship value is one of the assets we needed to be more focused on... I think it has to be done in a measured way because a lot of the importance of the collaboration is to have a strong relationship and it takes time to set that up.

Even though the social structure normally entails considerable flexibility, AIR has attempted to create some firmness by formalising social aspects of the relationship through its relationship profile tool. In one sense this could be described as shift from the social structure to the institutional structure. In other words, in order to preserve the fragile nature of inter-personal trust (at the social level) AIR is attempting to institutionalise its relationships with its suppliers. As such, the relationship profile tool reflects the need to combine firmness in the institutional structure with flexibility in the social structure. Here, we see AIR seeking to find an appropriate balance between firmness and flexibility in the minimal structures. Although the social structure can be used to govern the interpersonal aspects of the relationships, it may not be firm enough to govern relationships between the organisations - i.e., AIR and the suppliers' organisations - in the event of individuals changing their jobs. So, AIR is seeking to provide more firmness through the institutional structure in order to balance the flexibility in the social structure.

In this mutual dependence phase, a number of new elements emerged in the minimal structures (as illustrated in Table 5). The technical and social structures both became more important in the governance of the supply chain relationships than in the earlier phases. In this phase, as collaboration between AIR and its suppliers had become established, the need for technical and operational information for monitoring the 
performance of the supply chain became more intense than in the previous phase. Consequently, there was an increasing need for operational information about the supply chain relationships, and as a result the technical structure was very important in setting the technical context for the relationships between AIR and its suppliers.

Furthermore, in this phase, there was further evolution in the social structure as the governance mechanisms, such as the commodity strategies and the supplier, together with the relationship profile tool, set the social context for the relationships. Furthermore, collaboration between AIR and its suppliers created a need for the development of crossorganisational teams, and the sharing of accounting, technical and operational information. In addition, goodwill trust (i.e. the expectation that the other partner will act in the interests of the relationship - see Sako, 1992) was necessary for suppliers to be willing to share such information. The economic and institutional structures, which were the important structures in the early phases of the SCMM, were less important in this phase, although the introduction of the relationship profile tool and the need for goodwill trust suggest that these aspects of the institutional structure remain important for the maintenance of good relationships.

\section{---Insert Table 5 around here---}

\section{Discussion}

The research question which we set out in the Introduction was: how do minimal structures evolve as a company restructures its supply chain? In this final section we will draw on the findings of our case study to address this question and, in so doing, we will show how the minimal structures framework can be used to understand the way in which the governance of a supply chain evolves as it passes through the various phases of the SCMM. As we saw in the case study, there are different governance needs in each of the phases (see Table 6). 
In the (first) autonomous firm phase, which is typified by traditional supplier-buyer relationships, there is no collaboration and only limited interactions with the suppliers. As a result the governance of the supply chain relationships focusses on individual transactions and there are quite simple routines in place. In this phase the combination of the economic and institutional structures facilitate the governance of relatively straightforward market-based contractual relationships. The economic structure governs the market-based transactions and the institutional structure governs the context in which they take place.

The serial dependence phase, sometimes referred to as the 'breakthrough' phase (Lockamy \& McCormack, 2004), lays the foundations for collaboration between the company and its suppliers. Preferred suppliers are identified and encouraged to invest in the relationship, while the total number of suppliers is drastically reduced. Suppliers are most likely to be selected based on their significance for the manufacturing process and their willingness to collaborate with others in the supply chain. This is in line with Agndal and Nilsson (2009) who have pointed out that trust, capabilities, ability to work together and previous experience are more significant than the cost when selecting (preferred) suppliers. During this phase the economic structure continues to be important, especially in the identification of the preferred suppliers. However, the institutional structure becomes more important (than in the autonomous firm phase), as the institutional environment is likely to play an important role in the company's decision to restructure its supply chain and in the selection of the (preferred) suppliers. Although the governance of supply chain relationships remains quite 'mechanistic', especially in the way projects are allocated to suppliers, there is flexibility in the selection of the preferred suppliers. Furthermore, a social structure starts to emerge as such issues as trust and integrity become increasingly important in relationships with suppliers.

During the reciprocal dependence phase, when collaboration between the company and its suppliers strengthens, the economic and institutional structures (which were quite important in the previous phases) move into the 'background'. More flexible structures are now needed to enable new types of relationships to emerge. Increasing collaboration 
and greater integration across the supply chain generates a need for flexibility (Fredericks, 2005; Stevenson \& Spring, 2009). Here, the social structure, which started to emerge in the previous phase, now becomes increasingly important. For example, goodwill trust is needed for the sharing of information and the implementation of new governance mechanisms. Also, there is more social interaction between the company and its suppliers; for instance the nature of meetings between the parties becomes more collaborative and the personal interactions between the individuals involved become more important. In addition, a technical structure starts to emerge as the closer collaboration and the early supplier engagement increases the need for technical and accounting information.

During the (final) mutual dependence phase of the SCMM the technical structure becomes very important for the governance of the relationships, as it sets the technical and operational context for the relationships between the company and its suppliers. In contrast, the economic and institutional structures continue to remain in the 'background', while the social structure plays an increasingly important role in the governance of the relationships. However, in our case study we saw an attempt to formalise (i.e., institutionalise) some elements of the social structure, due to concerns about it being dependent on specific individuals (in both the case company and its suppliers) who might eventually change their jobs. In this way AIR effectively sought to limit the scope of the social structure and to replace it with elements of the institutional structure, in order to balance firmness and flexibility.

As indicated earlier, minimal structures provide sufficient structure (firmness), while leaving 'zones of manoeuvre' in which flexibility can be exercised. However, the way in which minimal structures provide firmness and flexibility can be different in different industries and in different supply chains, and even within the same supply chain over time. In the case study we saw shifts between formality and informality in the governance of AIR's supply chain. In the early phases (of the SCMM) AIR had a quite firm and formal approach, whereas there was more flexibility and informality in the subsequent phases. However, once the partnerships between AIR and its suppliers began to stabilise 
in the mutual dependence phase, AIR started to formalise some of the governance mechanisms. For example, it introduced the relationship profile tool. Thus, the various elements of the minimal structures can be more or less flexible at different times; i.e., firmness and flexibility can shift over time. Furthermore, elements of the minimal structures which were important in the earlier phases (specifically, the economic and institutional structures) became relatively less important in later phases, while the importance of the social and technical structures increased. As such, the minimal structures can be seen as a package (cf., Giovannoni \& Scapens, 2014; Malmi \& Brown, 2008) which works as a whole in the governance of the supply chain relationships. Each of the structures has to be seen in relation to the other structures, otherwise we will be unable to see how they achieve both firmness and flexibility. In our case study of AIR we saw how, in each of the phases of the SCMM, a shifting combination of minimal structures was needed to govern the supply chain relationships.

To summarise, in our case study we saw how the relative importance of the four minimal structures (economic, institutional, social and technical) changed over the different phases of the SCMM. Furthermore, the relationship between firmness and flexibility, and also between formality and informality, changed even within a specific phase of the SCMM. For example, as AIR is now in the (final) mutual dependence phase of the SCMM it has close collaborative relationships with the members of its supply chain. However, during the initial stages of the relationship with a specific supplier there can be flexibility in the technical structure, so as to facilitate the development of new technology. In addition, during the early supplier engagement AIR and the supplier jointly design target costs. However, this flexibility only exists until the project is allocated to the supplier, the price agreed and the contract signed. At this point, the technical structure becomes quite firm, and in the subsequent (manufacturing and delivery) stages of the project the relationship becomes much more structured (i.e., firmer). 


\section{Conclusion}

Due to the inter-disciplinary nature of our research, our paper contributes to various literatures. Firstly, we contribute to the SCM literature and, in particular, to the literature on the SCMM which emphasises that as a supply chain matures SCM relies less on the use of formal control mechanisms and more on collaboration and trust (Ballou et al., 2000; Handfield \& Bechtel, 2002; Seal et al., 1999; Spekman \& Carraway, 2006). Although our findings are generally consistent with that literature, we showed in our case study that even when its supply chain had achieved maturity (i.e., the final phase of the SCMM), AIR sought to formalise relationships with its suppliers through the development of a relationship profile tool. In addition, our findings highlight the significance of the social and institutional contexts of supply chain relationships which are generally ignored in the inter-organisational (accounting) literature (Scapens \& Varoutsa, 2010). Furthermore, there have been criticisms that the SCM literature is overly descriptive and lacks a theoretical dimension (see Chen and Paulraj, 2004; and Lambert and Cooper, 2000). By drawing on the minimal structures framework to analyse the phases of the SCMM, we have moved beyond simply describing the individual phases (and the tools and techniques which are used) and provided a more detailed understanding of the way in which a supply chain is governed as it moves through the various phases of the SCMM to achieve supply chain maturity. The minimal structures framework provides a way of analysing how the broader economic and institutional structures can combine with the social and technical structures to form a package which can be used in the governance of supply chain relationships.

Our research also contributes to the minimal structures literature by illustrating how minimal structures evolve over time. Although it has already been argued that minimal structures are likely to change over time (see van der Meer-Kooistra \& Scapens, 2008), this process is not documented in the literature. For example, van der Meer-Kooistra and Scapens claimed that minimal structures evolve, but they did not illustrate it in their paper (see 2008: p.381). They pointed out that in comparison with traditional management control systems, which provide information in a predetermined and highly structured form, and which are difficult (if not impossible) to adjust as circumstances 
change, minimal structures provide 'room for manoeuvre' (i.e., flexibility) for the parties to understand and react to emerging and new situations. By studying how minimal structures evolve through the different phases of the SCMM we have been able to explore the emergence and changing nature of minimal structures.

We have shown that in the early phases of the SCMM only a sub-set of the minimal structures are needed (the economic and institutional structures), but as collaborative relationships develop other structures (the social and technical structures) are also needed. We have also shown that the links between the different structures can be quite fluid, and that they can evolve and change as a supply chain moves through the different phases of the SCMM. Furthermore, even when a supply chain has reached the final maturity phase, the minimal structures may need to change as the individual projects move through their different stages (e.g., design and then manufacturing).

We also contribute to the broader literature on minimal structures by illustrating their usefulness in the context of supply chain management. The minimal structures framework has been used primarily for studying innovation, especially in new product development (Cunha \& Chia, 2007; Kamoche \& Cunha, 2001; Tatikonda \& Rosenthal, 2000; Vera, Nemanich, Vélez-Castrillón, \& Werner, 2014). In that context the literature usually focusses on the social and technical structures (Akgun, Byrne, Lynn, \& Keskin, 2007; Cunha \& Gomes, 2003). However, as we indicated earlier, van der Meer-Kooistra and Scapens (2008) extended the minimal structures framework by adding economic and institutional (minimal) structures. In their paper they illustrated their extended framework with two quite general examples of lateral relationships. In our paper we have applied their extended framework in the specific context of supply chain management and illustrated the usefulness of minimal structures in understanding the way in which a governance package (of the four minimal structures) can provide the necessary firmness and flexibility which are needed as a supply chain moves through the various phases of the SCMM. As such, we have generalised the minimal structures framework by demonstrating its usefulness in studying a new and quite specific context. 
Finally, our paper contributes to the inter-organisational control literature and in particular to discussions about the management control package (see, for example, Giovannoni \& Scapens, 2014; Malmi \& Brown, 2008; Sandelin, 2008). We avoided entering the debate about differences between a package and a system by using the minimal structures framework as a way of conceptualising a governance package (see van der Meer-Kooistra \& Scapens, 2008). The four minimal structures together form a package in providing the necessary firmness and flexibility in each of the phases of the SCMM. Furthermore, we have not discussed in detail the specific tools and techniques used in the various phases of the SCMM (see for example, Cullen \& Meira, 2010), although we did indicate some of the tools which AIR developed, especially during the reciprocal dependence and the mutual dependence phases. Instead, we have explored how the package of minimal structures (which could include accounting and management control techniques in the economic and/or technical structures) can be used in the different phases of the SCMM, and how they work with the social and institutional structures.

In this paper we have described an in-depth case study of supply chain restructuring in an aerospace manufacturing company. In so doing, we have drawn together the literature on inter-organisational control and supply chain management. We have responded to calls in the literature to study the process of supply chain evolution and to provide empirical evidence of the implementation of SCM (e.g., Halldorsson et al., 2008; Lambert and Cooper, 2000). The case study of AIR has enabled us to examine SCM in the aerospace industry from the perspective of a dominant partner, as AIR moved away from arm's length relationships with its suppliers to a more collaborative partnership-based model. We show how governance mechanisms can be applied to balance firmness and flexibility. By mapping the process of restructuring and identifying the structures needed to move through the different phases of the process leading to supply chain maturity, our findings can assist organisations which are seeking to restructure their supply chains.

In terms of practical implications, we believe our findings can help managers to understand better the process of supply chain restructuring. By drawing on the minimal 
structures framework we have illustrated how AIR restructured a particular supply chain. The experience of AIR has implications for other managers who want to restructure their supply chains. We have highlighted the structures that need to be considered and the importance of achieving a balance between firmness and flexibility - i.e., using minimal structures which provide room for manoeuvre to enable the parties involved to respond to changing situations. Thus, we have gone beyond simply looking at the specific accounting and management control techniques and explored how minimal structures (which include such techniques) can be used to govern supply chain relationships. Furthermore, the experience of AIR points to the need for a company to move through each of the phases of the SCMM, even though its ultimate aim is to achieve the final (mutual dependence) phase. A company is unlikely to be able to move from arm's length relationships to collaborative relationships in a single step. Some of the minimal structures (especially the technical and social structures) needed for the governance of collaborative relationships have to evolve, and cannot simply be designed and then put in place.

As indicated above, in this paper our focus has been on a dominant party which decided to restructure its supply chains. Although, in itself, it is useful to understand the way in which such a party can restructure its supply chain(s), it is nevertheless a limitation of our analysis. Future research is needed to study supply chain restructuring from the perspective of the other parties in the supply chain, in order to explore possible conflicts and resistance, and also to study the whole supply chain as a network of relationships. Another limitation is the particular industry focus of our study. The aerospace industry is highly regulated, with very high quality standards, and this will have had an influence on the minimal structures used to govern the supply chain. As such, the institutional structure may be more important in this industry than in others. Nevertheless, institutional factors are probably still important in other industries and so the institutional structure may be part of the minimal structures used in the governance of their supply chains. Thus, it would be useful to explore supply chain restructuring in less regulated industries. In such industries the balance within and between the minimal structures is likely to be different to the aerospace industry. Nevertheless, we believe that our approach of 
studying supply chain restructuring through an examination of the minimal structures will help in understanding SCM in other contexts. Furthermore, we believe that the minimal structures framework could be useful in studying other types of relationships in which a governance structure is needed to provide both firmness and flexibility, and in which the relationships evolve over time. 
Table 1 Overview of the Elements of the Four Structures

\begin{tabular}{|c|c|c|c|}
\hline Economic Structure & $\begin{array}{l}\text { Institutional } \\
\text { Structure }\end{array}$ & Social Structure & Technical Structure \\
\hline $\begin{array}{l}\text { Nature of market: } \\
\text { volatility and extent of } \\
\text { competition }\end{array}$ & $\begin{array}{l}\text { Law and governmental } \\
\text { regulations }\end{array}$ & $\begin{array}{l}\text { Behavioural norms and } \\
\text { values }\end{array}$ & $\begin{array}{l}\text { Basic knowledge of the } \\
\text { business }\end{array}$ \\
\hline $\begin{array}{l}\text { Visibility and } \\
\text { measurability of } \\
\text { performance and } \\
\text { efficiency }\end{array}$ & $\begin{array}{l}\text { Other institutional } \\
\text { regulations (e.g. ISO) }\end{array}$ & $\begin{array}{l}\text { Communication and } \\
\text { networking }\end{array}$ & $\begin{array}{l}\text { Technological } \\
\text { knowledge about } \\
\text { products and processes }\end{array}$ \\
\hline $\begin{array}{l}\text { Character of the } \\
\text { transactions: quality, } \\
\text { delivery, payment etc. }\end{array}$ & Type of contract & $\begin{array}{l}\text { Team-working and } \\
\text { information sharing }\end{array}$ & $\begin{array}{l}\text { Technical } \\
\text { competencies of } \\
\text { employees }\end{array}$ \\
\hline $\begin{array}{l}\text { Character of the } \\
\text { investments in physical } \\
\text { and non-physical assets }\end{array}$ & $\begin{array}{l}\text { Organisational } \\
\text { arrangements }\end{array}$ & Trust and integrity & $\begin{array}{l}\text { Information systems } \\
\text { and information } \\
\text { processing techniques }\end{array}$ \\
\hline $\begin{array}{l}\text { Frequency and volume } \\
\text { of the transactions }\end{array}$ & $\begin{array}{l}\text { Formal nature of the } \\
\text { relationship }\end{array}$ & Leadership role & $\begin{array}{l}\text { Available accounting } \\
\text { procedures and } \\
\text { techniques }\end{array}$ \\
\hline $\begin{array}{l}\text { Length of the } \\
\text { relationship }\end{array}$ & & $\begin{array}{l}\text { Arrangements for } \\
\text { individual and } \\
\text { organisational learning }\end{array}$ & \\
\hline
\end{tabular}

Source: van der Meer-Kooistra and Scapens (2008) p. 375

Table 2 Minimal Structures during the 'Autonomous Firm' Phase

\begin{tabular}{|c|c|c|c|}
\hline Economic Structure & $\begin{array}{l}\text { Institutional } \\
\text { Structure }\end{array}$ & Social Structure & Technical Structure \\
\hline $\begin{array}{l}\text { Character of the } \\
\text { transactions: quality, } \\
\text { delivery, payment etc. }\end{array}$ & $\begin{array}{l}\text { Law and governmental } \\
\text { regulations }\end{array}$ & & \\
\hline Contract & $\begin{array}{l}\text { Other institutional } \\
\text { regulations (e.g. ISO) }\end{array}$ & & \\
\hline
\end{tabular}


Table 3 Minimal Structures during the 'Serial Dependence' Phase

\begin{tabular}{|c|c|c|c|}
\hline Economic Structure & $\begin{array}{l}\text { Institutional } \\
\text { Structure }\end{array}$ & Social Structure & Technical Structure \\
\hline $\begin{array}{l}\text { Character of the } \\
\text { transactions: quality, } \\
\text { delivery, payment etc. }\end{array}$ & $\begin{array}{l}\text { Law and governmental } \\
\text { regulations }\end{array}$ & Trust and integrity & \\
\hline Contract & $\begin{array}{l}\text { Other institutional } \\
\text { regulations (e.g. ISO) }\end{array}$ & & \\
\hline $\begin{array}{l}\text { Importance in the } \\
\text { supply chain: } \\
\text { Frequency, volume and } \\
\text { asset specificity of the } \\
\text { transactions }\end{array}$ & $\begin{array}{l}\text { Organisational } \\
\text { arrangements }\end{array}$ & & \\
\hline $\begin{array}{l}\text { Nature of market: } \\
\text { volatility and extent of } \\
\text { competition }\end{array}$ & & & \\
\hline
\end{tabular}

Table 4 Minimal Structures during the 'Reciprocal Dependence' Phase

\begin{tabular}{|c|c|c|c|}
\hline Economic Structure & $\begin{array}{l}\text { Institutional } \\
\text { Structure }\end{array}$ & Social Structure & Technical Structure \\
\hline $\begin{array}{l}\text { Character of the } \\
\text { transactions: quality, } \\
\text { delivery, payment etc. }\end{array}$ & $\begin{array}{l}\text { Law and governmental } \\
\text { regulations }\end{array}$ & Trust and integrity & $\begin{array}{l}\text { Basic knowledge of the } \\
\text { business }\end{array}$ \\
\hline Contract & $\begin{array}{l}\text { Other institutional } \\
\text { regulations (e.g. ISO) }\end{array}$ & $\begin{array}{l}\text { Length of the } \\
\text { relationship }\end{array}$ & $\begin{array}{l}\text { Visibility and } \\
\text { measurability of } \\
\text { performance and } \\
\text { efficiency }\end{array}$ \\
\hline $\begin{array}{l}\text { Importance in the } \\
\text { supply chain: } \\
\text { Frequency, volume and } \\
\text { asset specificity of the } \\
\text { transactions }\end{array}$ & $\begin{array}{l}\text { Organisational } \\
\text { arrangements }\end{array}$ & & $\begin{array}{l}\text { Accounting } \\
\text { information sharing }\end{array}$ \\
\hline $\begin{array}{l}\text { Nature of market: } \\
\text { volatility and extent of } \\
\text { competition }\end{array}$ & & & \\
\hline
\end{tabular}


Table 5 Minimal Structures during the 'Mutual Dependence' Phase

\begin{tabular}{|c|c|c|c|}
\hline Economic Structure & $\begin{array}{l}\text { Institutional } \\
\text { Structure }\end{array}$ & Social Structure & Technical Structure \\
\hline $\begin{array}{l}\text { Character of the } \\
\text { transactions: quality, } \\
\text { delivery, payment etc. }\end{array}$ & $\begin{array}{l}\text { Law and governmental } \\
\text { regulations }\end{array}$ & Trust and integrity & $\begin{array}{l}\text { Basic knowledge of the } \\
\text { business }\end{array}$ \\
\hline Contract & $\begin{array}{l}\text { Other institutional } \\
\text { regulations (e.g. ISO) }\end{array}$ & $\begin{array}{l}\text { Length of the } \\
\text { relationship }\end{array}$ & $\begin{array}{l}\text { Visibility and } \\
\text { measurability of } \\
\text { performance and } \\
\text { efficiency }\end{array}$ \\
\hline $\begin{array}{l}\text { Importance in the } \\
\text { supply chain: } \\
\text { Frequency, volume and } \\
\text { asset specificity of the } \\
\text { transactions }\end{array}$ & $\begin{array}{l}\text { Organisational } \\
\text { arrangements }\end{array}$ & $\begin{array}{l}\text { Cross-organisational } \\
\text { and cross-functional } \\
\text { team-working }\end{array}$ & $\begin{array}{l}\text { Accounting } \\
\text { information sharing }\end{array}$ \\
\hline \multirow[t]{2}{*}{$\begin{array}{l}\text { Nature of market: } \\
\text { volatility and extent of } \\
\text { competition }\end{array}$} & $\begin{array}{l}\text { Formal nature of the } \\
\text { relationship }\end{array}$ & $\begin{array}{l}\text { Communication and } \\
\text { networking }\end{array}$ & $\begin{array}{l}\text { Technical Knowledge } \\
\text { about products and } \\
\text { processes }\end{array}$ \\
\hline & $\begin{array}{l}\text { Behavioural norms and } \\
\text { values }\end{array}$ & & $\begin{array}{l}\text { Cost Management } \\
\text { techniques }\end{array}$ \\
\hline
\end{tabular}

Table 6 The Emergence of Minimal Structures

\begin{tabular}{ll}
\hline $\begin{array}{l}\text { Supply Chain Maturity } \\
\text { Model Phases }\end{array}$ & Minimal Structures \\
\hline Autonomous Firm & $\begin{array}{l}\text { Economic structure largely governs the relationships } \\
\text { Institutional structure tends to exist prior to any specific projects }\end{array}$ \\
Serial Dependence & $\begin{array}{l}\text { Social structure started to emerge through the identification of preferred } \\
\text { suppliers and their encouragement to invest to the relationship }\end{array}$ \\
Reciprocal Dependence & $\begin{array}{l}\text { Social structure became more important for the governance of the } \\
\text { relationship - trust is needed for the implementation of the mechanisms, } \\
\text { investment in the relationship and disclosure of required information, } \\
\text { such as the suppliers' financial situation } \\
\text { Technical structure emerged through the early supplier engagement, and } \\
\text { emphasises suppliers' technological capabilities }\end{array}$ \\
Mutual Dependence & $\begin{array}{l}\text { Economic structure relatively unimportant } \\
\text { Technical structure is very important - implementation of target costing } \\
\text { and other mechanisms used to facilitate information sharing } \\
\text { The social structure becomes more formalised and moves towards the } \\
\text { institutional structure }\end{array}$
\end{tabular}




\section{Appendix A: Table of interviewees}

\section{Interviews conducted at AIR}

\begin{tabular}{|c|c|c|}
\hline No. & Date & Management Level \\
\hline 1 & September 2006 & $\begin{array}{l}\text { Financial Director } \\
\text { (Preliminary Meeting) }\end{array}$ \\
\hline 2 & March 2007 & $\begin{array}{l}\text { Financial Director } \\
\text { (Second Interview) }\end{array}$ \\
\hline 3 & March 2007 & $\begin{array}{l}\text { Purchasing Manager I } \\
\text { (First Interview) }\end{array}$ \\
\hline 4 & March 2007 & Purchasing Manager II \\
\hline 5 & June 2007 & $\begin{array}{l}\text { Operations Purchasing Executive } \\
\text { (First Interview) }\end{array}$ \\
\hline 6 & June 2007 & $\begin{array}{l}\text { Financial Controller } \\
\text { (First Interview) }\end{array}$ \\
\hline 7 & June 2007 & $\begin{array}{l}\text { Business Finance Partner for Subsidiaries and JVs } \\
\text { (First Interview) }\end{array}$ \\
\hline 8 & September 2007 & $\begin{array}{l}\text { JV Relationship Manager } \\
\text { (First Interview) }\end{array}$ \\
\hline 9 & November 2007 & $\begin{array}{l}\text { Operations Manager I } \\
\text { (First Interview) }\end{array}$ \\
\hline 10 & November 2007 & Operations Manager II \\
\hline 11 & November 2007 & $\begin{array}{l}\text { Management Accountant } \\
\text { (First Interview) }\end{array}$ \\
\hline 12 & March 2008 & $\begin{array}{l}\text { Operations Purchasing Executive } \\
\text { (Second Interview) }\end{array}$ \\
\hline 13 & March 2008 & Financial Director of Operations \\
\hline 14 & April 2008 & $\begin{array}{l}\text { Purchasing Manager I } \\
\text { (Second Interview) }\end{array}$ \\
\hline 15 & April 2008 & $\begin{array}{l}\text { Financial Controller } \\
\text { (Second Interview) }\end{array}$ \\
\hline 16 & May 2008 & $\begin{array}{l}\text { Business Finance Partner for Subsidiaries and JVs } \\
\text { (Second Interview) }\end{array}$ \\
\hline 17 & May 2008 & $\begin{array}{l}\text { Operations Manager I } \\
\text { (Second Interview) }\end{array}$ \\
\hline 18 & June 2008 & $\begin{array}{l}\text { Management Accountant } \\
\text { (Second Interview) }\end{array}$ \\
\hline 19 & June 2008 & $\begin{array}{l}\text { JV Relationship Manager } \\
\text { (Second Interview) }\end{array}$ \\
\hline 20 & March 2009 & $\begin{array}{l}\text { Purchasing Manager I } \\
\text { (Third Interview) }\end{array}$ \\
\hline
\end{tabular}




\section{Appendix B NVivo Nodes}

\begin{tabular}{|c|c|}
\hline Free Nodes & Tree Nodes \\
\hline $\begin{array}{l}\text { 1. Reasons for supply chain } \\
\text { restructuring }\end{array}$ & $\begin{array}{l}\text { 1. Joint ventures } \\
\text { a. Reasons for creation } \\
\text { b. Before changes } \\
\text { c. Contract } \\
\text { d. KPIs } \\
\text { e. Management control techniques } \\
\text { f. Other partner relationships }\end{array}$ \\
\hline 2. Manufacturing Process & $\begin{array}{l}\text { 2. Long-term agreements } \\
\text { a. Before changes } \\
\text { b. Benefits } \\
\text { c. Contract } \\
\text { d. After changes }\end{array}$ \\
\hline 3. Operations & $\begin{array}{l}\text { 3. Subsidiary } \\
\text { a. Comparison with joint ventures } \\
\text { b. Equality internal - external suppliers }\end{array}$ \\
\hline 4. Relationship Management & $\begin{array}{l}\text { 4. Mechanisms } \\
\text { a. Supplier Scorecard } \\
\text { b. QCDR reviews } \\
\text { c. STEP } \\
\text { d. Relationship Profile Tool }\end{array}$ \\
\hline 5. Commodity Strategy & $\begin{array}{l}\text { 5. Accounting Techniques } \\
\text { a. Cost information sharing } \\
\text { b. Target costing }\end{array}$ \\
\hline 6. Supplier Strategy & $\begin{array}{l}\text { 6. Supply Chain Strategy } \\
\text { a. Initial thoughts for changes } \\
\text { b. Reasons for changes } \\
\text { c. Resource work }\end{array}$ \\
\hline 7. Trust & \\
\hline
\end{tabular}




\section{References}

Agndal, H., \& Nilsson, U. (2009). Interorganizational cost management in the exchange process. Management Accounting Research, 20(2), 85-101.

Akgun, A. E., Byrne, J. C., Lynn, G. S., \& Keskin, H. (2007). New product development in turbulent environments: Impact of improvisation and unlearning on new product performance. Journal of Engineering and Technology Management, 24:0B]', 203-230.

Akkermans, H., Bogerd, P., \& Vos, B. (1999). Virtuous and vicious cycles on the road towards international supply chain management. International Journal of Operations and Production Management, 19(5/6), 565-581.

Alvarado, U. Y., \& Kotzab, H. (2001). Supply chain management: the integration of logistics in marketing. Industrial Marketing Management, 30(183-198).

Ballou, H. R., Gilbert, M. S., \& Mukherjee, A. (2000). New managerial challenges from supply chain opportunities. Industrial Marketing Management, 29, 7-18.

Barratt, M. (2004). Understanding the meaning of collaboration in the supply chain. Supply Chain Management: An International Journal, 9(1), 30-42.

Berry, A. J., Ahmed, A., Cullen, J., Dunlop, A., \& Seal, W. (2000). The consequences of inter-firm supply chains for management accounting. London: CIMA.

Brown, S. L., \& Eisenhardt, K. M. (1997). The art of continuous change: linking complexity theory and time-paced evolution in relentlessly shifiting organizations. Administrative Science Quarterly, 42, 1-34.

Caglio, A., \& Ditillo, A. (2008). A review and discussion of management control in interfirm relationships: Achievements and future directions. Accounting, Organizations and Society, 33, 865-898.

Caglio, A., \& Ditillo, A. (2012). Opening the black box of management accounting information exchanges in buyer-supplier relationships. Management Accounting Research, 23(2), 61-78.

Chen, I. J., \& Paulraj, A. (2004). Understanding supply chain management: critical research and a theoretical framework. international Journal of Production Research, 42(1), 131-163.

Christopher, M. (2000). The Agile Supply Chain: Competing in Volatile Markets. Industrial Marketing Management, 29(1), 37-44.

Coad, A. F., \& Cullen, J. (2006). Inter-organisational cost management: Towards an evolutionary perspective. Management Accounting Research, 17, 342-369.

Cooper, R., \& Slagmulder, R. (1999). Supply chain development for the lean enterprise. Interorganizational cost management. Portland, OR: Productivity Press.

Cooper, R., \& Slagmulder, R. (2004). Interorganizational cost management and relational context. Accounting, Organizations and Society, 29(1), 1-26.

Cox, A. (1999). Power, value and supply chain management. Supply Chain Management: An International Journal, 4(4), 167-175.

Cullen, J., \& Meira, J. (2010). Inter-organisational accounting in dyadic settings. In H. Håkansson, K. Kraus \& J. Lind (Eds.), Accounting in networks. New York Routledge.

Cunha, M., \& Chia, R. (2007). Using Teams to Avoid Peripheral Blindness. Long Range Planning, 40, 559-573. 
Cunha, M., \& Gomes, J. F. S. (2003). Order and Disorder in Product Innovation Models. Creativity and Innovation Management, 12(3), 174-187.

Dekker, H. C. (2003). Value chain analysis in interfirm relationships: A field study. Management Accounting Research, 14, 1-23.

Deloitte. (2009). Out of the shadows: Why supply chain strategy should be at the top of the corporate agenda. Aerospace and Defence Industry Group.

Ellram, L. M. (2006). The implementation of target costing in the United States: Theory versus practice. Journal of Supply Chain Management, Winter, 13-25.

Emerson, R. M., Fretz, R. L., \& Shaw, L. L. (1995). Writing ethnographic fieldnotes. Chicago: University of Chicago Press.

Fredericks, E. (2005). Infusing flexibility into business-to-business firms: A contingency theory and resource-based view perspective and practical implications. Industrial Marketing Management, 34, 555-565.

Gadde, L.-E., \& Håkansson, H. (2001). Supply network strategies. Chichester: Wiley.

Gadde, L.-E., \& Snehota, I. (2000). Making the most of supplier relationships. Industrial Marketing Management, 29, 305-316.

Giovannoni, E., \& Scapens, R. W. (2014). Managing the tensions of innovation in a knowledge intensive firm: The coherence of an (in)/formal management control package. Working paper.

Håkansson, H., \& Lind, J. (2007). Accounting in an interorganisational setting. In C. S. Chapman, A. G. Hopwood \& M. D. Shields (Eds.), Handbook of management accounting research (Vol.2) (pp. 885-902). Oxford: Elsevier.

Halldórsson, A., Larson, P. D., \& Poist, R. F. (2008). Supply chain management: a comparison of Scandinavian and American perspectives. International Jounal of Physical Distribution \& Logistics Management, 38(2), 126-142.

Handfield, B. R., \& Bechtel, C. (2002). The role of trust and relationship structure in improving supply chain responsiveness. Industrial Marketing Management, 31, 367-382.

Johnsen, T., Johnsen, R., \& Lamming, R. (2008). Supply relationship evaluation: The relationship assessment process (RAP) and beyond. European Management Journal, 26, 274-287.

Jüttner, U., Christopher, M., \& Baker, S. (2007). Demand chain management-integrating marketing and supply chain management. Industrial Marketing Management, 36(3), 377-392.

Kajüter, P., \& Kulmala, H. I. (2005). Open-book accounting in networks: Potential achievements and reasons for failures. Management Accounting Research, 16(2), 179-204.

Kamoche, K., \& Cunha, M. (2001). Minimal structures: From jazz improvisation to product innovation. Organization Studies, 22(5), 733-764.

Kampstra, R. P., Ashayeri, J., \& Gattorna, J. L. (2006). Realities of supply chain collaboration. International Journal of Logistics Management, 17(3), 312-320.

Kotzab, H., Grant, D. B., \& Friis, A. (2006). Supply chain management implementation and priority strategies in Danish organizations. Journal of Business Logistics, 27(2), 273-300.

Lambert, M. D., \& Cooper, C. M. (2000). Issues in Supply Chain Management. Industrial Marketing Management, 29, 65-83. 
Lambert, M. D., Cooper, C. M., \& Pagh, D. J. (1998). Supply chain management: implementation issues and research opportunities. The International Journal of Logistics Management, 9(2).

Lamming, R. (1993). Beyond partnership, strategies for innovation and lean supply. New York: Prentice-Hall.

Langley, A. (1999). Strategies for theorizing from process data. Academy of Management Review, 24(4), 691-710.

Leonard-Barton, D. (1990). A dual methodology for case studies: Synergistic use of a longitudinal single site with replicated multiple sites. Organization Science, 1(3), 248-266.

Lincoln, Y. S., \& Guba, E. G. (1985). Naturalistic inquiry. Beverly Hills, California: Sage Publisher.

Lockamy, A., \& McCormack, K. (2004). The development of a supply chain management process maturity model using the concepts of business process orientation. Supply Chain Management: An International Journal, 9(4), 272-278.

Lockamy, A., \& Smith, W. I. (2000). Target costing for supply chain management: Criteria and selection. INdustrial Management and Data Systems, 100(5), 210218.

Malmi, T., \& Brown, D. A. (2008). Management control systems as a package-Opportunities, challenges and research directions. Management Accounting Research, 19(4), 287-300.

McCormack, K., Ladeira, M. B., \& Oliveira, M. P. V. (2008). Supply chain maturity and performance in Brazil. Supply Chain Management: An International Journal, 13(4), 272-282.

McKinnon, J. L. (1988). Reliability and Validity in Field Research: Some Strategies and Tactics. Accounting, Auditing \& Accountability Journal, 1(1), 34-54.

Miles, M. B., \& Huberman, M. A. (1994). Qualitative data analysis: An expanded sourcebook. London: Sage Publications.

Mortensen, M. H., Freytag, P. V., \& Arlbjørn, J. S. (2008). Attractiveness in supply chains: a process and matureness perspective. International Jounal of Physical Distribution \& Logistics Management, 38(10), 799-815.

Mouritsen, J., Hansen, A., \& Hansen, C. O. (2001). Inter-organizational controls and organizational competencies: episodes around target cost management/functional analysis and open book accounting Management Accounting Research, 12(2), 221-244.

Nooteboom, B. (1999). Interfirm Alliances: analysis and design. London: Routledge.

Nooteboom, B. (2002). Trust: Forms, foundations, functions, failures and figures: Edward Elgar.

Oliveira, M. P. V., McCormack, K., \& Trkman, P. (2012). Business analytics in supply chains - The contigent effect of business process maturity. Expert Systems with Applications, 39, 5488-5498.

Rose-Anderssen, C., Allen, P. M., Tsinopoulos, C., \& McCarthy, I. (2005). Innovation in manufacturing as an evolutionary complex system. Technovation, 25, 1093-1105.

Rose-Anderssen, C., Baldwin, J. S., Ridgway, K., Allen, P. M., Varga, L., \& Strathern, M. (2006). Emerging practices in commercial aerospace supply chains. Paper 
presented at the Fourth Nordic Conference on Cultural and Activity Research, Oslo, Norway.

Rosenthal, S. R. (1992). Effective product design and development. Irwin: Homewood, IL.

Ryan, B., Scapens, R. W., \& Theobold, M. (2002). Research methods and methodology in finance and accounting. London: Thomson.

Sako, M. (1992). Prices, quality and trust: Inter-firm relationships in Britain and Japan. Cambridge: Cambridge University Press.

Sandelin, M. (2008). Operation of management control practices as a package - A case study on control system variety in a growth firm context. Management Accounting Research, 19, 324-343.

Scannell, T. V., Vickery, S. K., \& Droge, C. L. (2000). Upstream supply chain management and competitive performance in the automotive supply industry. Journal of Business Logistics, 21(1), 23-48.

Scapens, R. W., \& Varoutsa, E. (2010). Accounting in inter-organisational relationships: The institutional theory perspective. In H. Håkansson, K. Kraus \& J. Lind (Eds.), Accounting in networks. New York: Routledge

Seal, W., Cullen, J., Dunlop, A., Berry, A., \& Ahmed, M. (1999). Enacting a European supply chain: a case study on the role of management accounting. Management Accounting Research, 10(3), 303-322.

Shimizu, I. (1996). The Dark Side of Japanese Business. New York, NY: M.E. Sharpe, Armonk.

Spekman, R. (1988). Strategic supplier selection: understanding long-term buyer relationships. Business Horizons, 31, 75-81.

Spekman, R., \& Carraway, R. (2006). Making the trasition to collaborative buyer-seller relationships: An emerging framework. Industrial Marketing Management, 35, 10-19.

Spekman, R., Kamauff, W. J., \& Myhr, N. (1998). An empirical investigation into supply chain management: a perspective on partnerships. Supply Chain Management, 3(2), 53-67.

Stevenson, M., \& Spring, M. (2009). Supply chain flexibility: An inter-firm empirical study. International Journal of Operations and Production Management, 29(9), 946-971.

Storey, J., Emberson, C., Godsell, J., \& Harrison, A. (2006). Supply chain management: theory, practice and future challenges. International Journal of Operations and Production Management, 26(7), 754-774.

Strauss, A. (1987). Qualitative analysis for social scientists. Cambridge, UK: Cambridge University Press.

Tatikonda, M. V., \& Rosenthal, S. R. (2000). Successful execution of product development projects: Balancing firmness and flexibility in the innovation process. Journal of Operations Management, 18, 401-425.

Van de Ven, A. H., \& Ferry, D. L. (1980). Measuring and assessing organizations. New York: Wiley-Interscience.

van der Meer-Kooistra, J., \& Vosselman, E. G. J. (2000). Management Control of interfirm transactional relationships: the case of industrial renovation and maintenance. Accounting, Organizations and Society, 25(1), 51-77. 
Varoutsa, E. (2011). The role of management accounting and control in interorganisational relationships: A case study in the aerospace industry. (PhD Thesis), University of Manchester, UK.

Vera, D., Nemanich, L., Vélez-Castrillón, S., \& Werner, S. (2014). Knowledge-Based and Contextual Factors Associated with R\&D Teams' Improvisation Capability. Journal of Management, forthcoming.

Wagner, M. S., Lukassen, P., \& Mahlendorf, M. (2010). Misused and missed use Grounded theory and objective hermeneutics as methods for research in industrial marketing. Industrial Marketing Management, 39, 5-15. 